\title{
MI ISTIQOMAH SAMBAS: PROFIL MADRASAH UNGGUL DI KABUPATEN PURBALINGGA
}

\author{
MI ISTIQOMAH SAMBAS: PROFILE OF SUPERIOR \\ MADRASAH IN PURBALINGGA REGENCY
}

\author{
Suprapto \\ Peneliti Puslitbang Pendidikan Agama dan Keagamaan \\ Jl. M.H. Thamrin No. 6 Jakarta Pusat \\ Puslitbangpenda@yahoo.co.id
}

\begin{abstract}
The performance of superior madrasah has not been disseminated well in the public while it can be used as a model to improve the madrasah management quality. The study aims to know the superiority and particularity of the superior madrasah for reference in improving the quality and competitiveness of madrasah in the future. The method use is qualitative using interview, observation and documentation. The study focus is MI Istiqomah Sambas (MIIS) Purbalingga Central Java. The superiority and particularity are its programmed educational services such as madrasah management based on Quality Management system, acceleration (accelerated learning term) program, Koran reciting tutoring and service with UMMI system, Qiraatul Kutub, promotion and degradation and IT-based learning. MI Istiqomah Sambas has been equipped with adequate educational facilities and infrastructure. MIIS develops the principle of management in the form of Total Product Concept through Generic, Expected, Augmented and Potential Phases. In the future MIIS needs to increase the educational service quality for creating superior, independent, creative students under Islamic spirituality by involving all stakeholders.
\end{abstract}

Keywords: Superior Madrasah Ibtidaiyah

\begin{abstract}
Abstrak
Performa madrasah unggul belum tersosialisasi secara meluas di masyarakat padahal madrasah tersebut dapat dijadikan model dalam rangka peningkatan mutu pengelolaan madrasah. Penelitian ini bertujuan untuk mengetahui keunggulan dan kekhasan madrasah unggul untuk dijadikan referensi dalam peningkatan mutu dan daya saing madarasah ke depan. Metode penelitian yang digunakan adalah kualitatif dengan teknik wawancara, observasi dan studi dokumentasi. Lokus penelitian ini dilakukan di MI Istiqomah Sambas (MIIS) Purbalingga Jawa Tengah. Keunggulan dan kekhasan madrasah ini yaitu pada layanan pendidikan yang diprogramkan seperti pengelolaan madrasah berbasis Sistem Manajemen Mutu, program akselerasi (percepatan waktu belajar), bimbingan baca Qur'an dan ibadah dengan sistem UMMI, Qiraatul Kutub, promosi dan degradasi, dan pembelajaran berbasis IT. MI Istiqomah Sambas telah dilengkapi sarana dan prasarana penyelenggaraan pendidikan yang cukup memadai. MIIS mengembangkan azas tata kelola dalam bentuk Total Product Concept melalui tahapan Generic, Ekspective, Aughmented dan Potencial. Ke depannya MIIS perlu meningkatkan mutu pelayanan pendidikan untuk membentuk peserta didik yang unggul, mandiri, kreatif dan Islami dengan melibatkan seluruh stakeholders.
\end{abstract}

Kata Kunci: Madrasah Ibtidaiyah Unggul 


\section{PENDAHULUAN}

Pendidikan memiliki peranan penting dalam kehidupan manusia, sehingga pendidikan tidakterlepas dari kehidupan kita sehari-hari. Dalam hal ini pemerintah perlu mendorong hadirnya sekolah yang bermutu atau berkeunggulan. Sekolah unggulan merupakan sekolah yang diciptakan untuk memberikan keunggulan pada keluaran dalam pendidikan dan dikembangkan untuk mencapai keunggulan. Dan untuk mencapai keunggulan tentunya ada banyak faktor yang mempengaruhinya seperti proses dari pendidikan, tenaga dan guru kependidikan, proses layanan pendidikan, manajemen, dan sara penunjang yang berfungi untuk mencapai tujuan pendidikan.

Lembaga pendidikan yang mengatas namakan dirinya sebagai sekolah unggulan harus diakui oleh pemerintah dan masyarakat, bukan oleh lembaga atau sekolah itu sendiri. Karena keunggulan berarti memiliki nilai yang lebih dibanding dengan sekolah/madrasah yang lain dan tentunya nilai itu tidak hanya dapat dilihat dari aspek fisik, melainkan juga aspek-aspek lain yang sangat menentukan. Misalnya proses pembelajarannya ataupun output yang dihasilkan. Begitupun juga sekolah yang mendapat predikat sekolah model dari pemerintah harus mampu menunjukkan dirinya sebagai sekolah yang layak dan pantas untuk dicontoh oleh sekolah atau madrasah lainnya.

Madrasah unggulan merupakan tempat berlangsungnya kegiatan belajar mengajar (KBM) yang menawarkan mutu dari prestasi yang telah diraih dan kemampuan yang dapat dicapai secara terukur dari madrasah tersebut. Madrasah unggulan sering kali diartikan sebagai madrasah yang bermutu, karena kualitas output yang diberikan dari lembaga itu sudah memberikan bukti yang nyata, dan berbagai apresiasi yang didapat dari berbagai kalangan, serta bukti nyata yang diraih dari berbagai jenis perlombaan dan kemampuan anak didik dalam meraih prestasi akademik yang tidak lepas dari faktor pendukung yang ada di madrasah unggulan. Madrasah yang mengedepankan prestasi pasti lebih mengarahkan dan menekankan kepada iklim yang mendukung dilingkungan madrasah seperti proses belajar yang positif, dan kondisi kegiatan belajar yang produktif.

Sejak diberlakukannya Undang-undang No.20 Tahun 2003 tentang sistem pendidikan Nasional yang menempatkan madrasah sebagai bagian dari subsistem pendidikan nasional.Posisi madrasah sudah benar-benar sejajar dengan sekolah pada umumnya, karena pemerintah melalui PP no 19/2005 tentang Standar Nasional Pendidikan dan Permendiknas No 22, 23, 24 tahun 2006, telah memberikan standarisasi baik isi, proses, pengelolaan dan penilaian terhadap semua bentuk dan jenis pendidikan formal di Indonesia mulai dari tingkat dasar sampai pendidikan tinggi baik yang berupa sekolah umum maupun madrasah. Dengan statusnya kini, madrasah dituntut untuk melakukan inovasi dan pembaharuan diri baik secara kelembagaanmaupun dari sisi mutu. Keberadaan madrasah di Indonesia sejak lima tahun terakhir betul-betul menunjukan eksistensi yang terus menguat, baik secara kuantitatif maupun kualitatif. Secara kuantitatif, rata-rata pertumbuhan jumlah madrasah (RA, MI, MTs, MA) meningkat 4,7\% sejak tahun 2010. Hingga padatahun 2014, terdapat28.627 Raudlatul Athfal 
(RA), 24.592 Madrasah Ibtidaiyah (MI), 16.460 Madrasah Tsanawiyah (MTs), dan 7.046 Madrasah Aliyah (MA). Pada saat ini tercatat sebanyak 1.159.020 siswa RA, 3.404.089 siswa MI, 2.849.243 siswa MTs, dan 1.100.939 siswa MA. Pertumbuhan siswa juga cenderung meningkat sejak tahun 2010 yaitu sekitar 3,6\% per tahun. Secara kualitatif, sudah banyak bermunculan madrasahmadrasah baru dengan berbagai model dan keunggulan pendidikannya seperti madrasah unggulan Ibtidaiyah Negeri (MIN) 1 Malang, Jawa Timur, MTsN 3 dan MAN 3 Jalan Bandung Malang Jawa Timur, MI dan MTs Pembangunan Kompleks UIN Syarif Hidayatullah, Jakarta, MAS Al-Irsyad Demak, Jawa Tengah, MAN Insan Cendikia Serpong, dan sebagainya. Madrasah-madrasah tersebut telah membuktikan dirinya bahwa mereka memiliki banyak keunggulan yang dibuktikan dengan berbagai prestasi baik dalam skala nasional maupun internasional. ${ }^{1}$

Permasalahannya, performa madrasah unggul belum tersosialisasi secara meluas. Padahal madrasah-madrasah seperti inilah yang akan dijadikan contoh dan akan dikembangkan di beberapa tempat di seluruh Indonesia. Disamping itu bagaimana input, keunggulan dan kekhasan, output, strategi dan faktor pendukung dan penghambat dalam penyelenggaraan pendidikan di MI unggulan?

Hasil penelitian ini diharapkan dapat bermanfaat sebagai bahan masukan kepada Ditjen Pendidikan Islam Kementerian Agama, khususnya Direktorat Madrasah

\footnotetext{
${ }^{1}$ Makalah Direktur Madrasah, Dedi Zubaidi yang diprentasikan pada acara Workshop Perencanaan Puslitbang Penda dan Keagamaan, tanggal 25 Pebruari 2015 di Gedung Pusdiklat Kementerian Agama Ciputat, Banten.
}

Kementerian Agama dalam mengambil kebijakan dalam rangka peningkatan mutu dandayasaing MadrasahIbtidaiyah(MI).Bagi penyelenggara Madrasah dapat dijadikan referensi dalam upaya meningkatkan mutu dan daya saing madrasah.

\section{Kerangka Konseptual}

\section{Pengertian Madrasah Unggul}

Sekolah unggul dalam perspektif Departemen Pendidikan Nasional adalah sekolah yang dikembangkan untuk mencapai keunggulan dalam keluaran (output) pendidikannya. Untuk mencapai keunggulan tersebut maka masukan (input), proses pendidikan, guru dan tenaga kependidikan, manajemen, layanan pendidikan, serta sarana penunjangnya harus diarahkan untuk menunjang tercapainya tujuan tersebut. ${ }^{2}$ Mastuhu dalam buku yang berjudul "Menata Ulang Pendidikan Nasional Abad 21" mengemukakan bahwa konsep sekolah/madrasah unggul berangkat dari proses manajemen yang mendesain sedemikian rupa konsistensi visi dan misi serta konsistensi tujuan dengan target diimplementasikan dalam program kerja dengan mengakomodir keinginan lingkungan strategis (internal dan eksternal) dengan mengacu pada ukuran kualitas yang ditentakan. ${ }^{3}$ Penjelasan ini memberikan gambaran konsep madrasah unggulan bahwa untuk mencapai keunggulan tersebut maka masukan (input), proses pendidikan, guru dan tenaga kependidikan, manajemen, layanan pendidikan, serta

${ }^{2}$ Muhammad. Konsep Pengembangan Madrasah Unggul. Kreatif, Vol. 4, No. 1 (Januari 2009), 39.

3 Mastuhu. 2002. Menata Ulang Pendidikan Nasional Abad 21. Jakarta: INIS, h. 78 
sarana penunjangnya harus diarahkan untuk menunjang tercapainya tujuan tersebut. Menurut Abudinata, madrasah ungulan adalah madrasah yang memadukan antara keungulan dalam bidang sains, ketrampilan dan teknologi dengan keunggulan dalam bidang pengetahuan keagamaan termasuk di dalamnya keunggulan dalam keimanan dan ketaqwaan. ${ }^{4}$ Sedangkan menurut Maimun dan Fitri, Madrasah memilki keungggulan jika inputnya (siswa) potensial, proses berkualitas (tujuan, pendidik, siswa, bahan, metode/ sarana, dana, alat media dan manajemen), Outputputnya berkualitas (alumni) dan outcomenya baik (alumni yang bergabung dengan masyarakat. ${ }^{5}$

Menurut Nur Azizah, madrasah unggul harus memiliki dua jenis keunggulan, yaitu: Pertama, keunggulan Komparatif. Keunggulan komparatif dalam konteks lembaga pendidikan adalah keunggulan yang berkaitan dengan sumber daya yang disediakan, dimiliki tanpa perlu adanya suatu upaya. Kedua, keunggulan Kompetitif. Keunggulan kompetitif adalah keunggulan yang timbul karena ada suatu upaya yang dilakukan untuk mencapainya. Keunggulan kompetitif terkait dengan daya saing Madrasah yang memiliki keunggulan kompetitif akan terus mengejar prestasinya sehingga mampu bersaing dengan madrasah lain, walaupun sudah mendapat bantuan dari pemerintah. Madrasah unggulan ini tetap dan terus berusaha meningkatkan

${ }^{4}$ Abudinata. 2011. Reposisi Madarsah dalam Memasuki Indonesia Baru, makalah disampaikan pada seminar Evaluasi Kurikulum Madarsah Tahun 1994 (Jakarta: Litbang Depag RI, 6-7 Desember 1999), h. 8

5 Agus Maimun dan Agus Zaenul Fitri. 2010. Sekolah Unggulan Lembaga Pendidikan Alternatif di Era Kompetitif. Malang: UIN Maliki Press, h. 26. kualitas keunggulannya, baik dalam hal manajemennya maupun outputnya. Dengan demikian madrasah unggulan dapat didefinisikan sebagai madrasah yang dikembangkan dan dikelola sebaik-baiknya dengan mengarahkan semua komponennya untuk mencapai hasil lulusan yang lebih baik dan cakap daripada lulusan madrasah lainnya.

\section{Karakteristik Madrasah Unggul}

Fasli Jalal, dalam slide presentasinya tentang karakteristik sekolah unggul atau sekolah efektif mengutip riset Harris and Bennett tahun 2001 dalam School Effectiveness Research: Meta Analysis yaitu: 1) Kepemimpinan yang profesional (Professional Leadership),2) Visi dantujuanbersama(Shared Vision and Goals), 3) Lingkungan belajar (a Learning Environment), 4) Konsentrasi pada belajar-mengajar (Concentration on Learning and Teaching), 5) Harapan yang tinggi (High Expectation),6) Penguatan/ pengayaan/pemantapan yang positif (Positive Reinforcement), 7) Pemantauan kemajuan (Monitoring Progress, 8) Hak dan tanggung jawab peserta didik (Pupil Rights and Responsibility).9) Pengajaran yang penuh makna (Purposeful Teaching), 10) Organisasi pembelajar (a Learning Organization), 11) Kemitraan keluarga-sekolah (Home-School Partnership). ${ }^{6}$ Menurut Johar karakteristik madrasah unggulan adalah: 1) Memilki keunggulan IPTEK, 2) Punya tujuam visi, dan misi, 3) guru-guru kompeten, 4) kurikulum dapat dipertanggungjawabkan secara teoritik dan empirik, 5) metode

${ }^{6}$ Fasli Jalal,. 2012. Slide presentasi Strategi dan Arah Pengembangan Sekolah Unggul,diunduh tangal 12 Juni 2012 
dan pendekatnnya sesuai, 6) siswanya mempunya kompetensi untuk maju, 7) danya memadai, 8) saranya lengkap, 9) kegiatannya dapat menumbuhkan tradisi ilmiah dan amaliyah, 10) partisipasi dan kepercayaan masyarakat besar, 11) kualitras lulusannya sangat memuaskan. ${ }^{7}$ Madrasah/ Sekolah unggulan perlu di tunjang dengan berbagai aspek, di antaranya input yang unggul, guru yang professional, sarana memadai, kurikulum yang inovatif,ruang kelas atau pembelajaran yang representatif, sehingga dapat menciptakan keluaran (output) yang unggul dan berkualitas.

Depdikbud mengemukakan dimensidimensi keunggulan sebagai ciri sekolah unggul adalah: Pertama, Masukan (input) yaitu siswa yang terseleksi ketat dengan menggunakan kriteria tertentu: a) prestasi belajar superior dengan indikator nilai rapor, nilai Ebtanas Murni (NEM), dan hasil tes prestasi akademik,(b) skor psikotes (intelegensi dan kreativitas), dan c) tes fisik jika diperlukan. Kedua, Sarana dan prasarana yang menunjang kebutuhan belajar siswa serta menyalurkan minat dan bakatnya (kurikuler dan ekstrakurikuler). Ketiga, Lingkungan belajar yang kondusif baik lingkungan fisik maupun sosial psikologis. Keempat, Guru dan tenaga kependidikan yang menangani harus unggul baik dari penguasaan materi pelajaran, metode mengajar, maupun komitmen dalam melaksanakan tugas. Untuk itu perlu disediakan insentif tambahan bagi guru berupa uang maupun fasilitas lainnya. Kelima, Kurikulumnya diperkaya dengan pengembangan dan improvisasi secara

${ }^{7}$ Djohar. 2002. Pendidikan: Alternatif Pendidikan Masa Depan. Yogyakarta: LESFI, h. 63 maksimal sesuai dengan tuntutan belajar peserta didik yang memiliki kecepatan belajar serta motivasi belajar yang lebih tinggi dibanding dengan siswa yang seusianya. Keenam, waktu belajarnya, lebih lama dibanding dengan sekolah lain. Karena bertambahnya materi kurikulum dan atau waktu pembelajaran di luar jam belajar yang telah ditetapkan. Ketujuh, Proses belajar mengajar harus berkualitas dan hasilnya dapat dipertanggungjawabkan (accountable) baik kepada siswa, lembaga maupun masyarakat.

Sejalan dengan dimensi-dimensi sebagai ciri sekolah unggul, menurut Djoyonegoro Sekolah unggulan adalah sekolah yang mempunyai indikator : (1) prestasi akademik dan non akademik di atas rata-rata sekolah di daerahnya, (2) sarana dan prasarana serta layanan yang lebih lengkap, (3) sistem pembelajaran lebih baik dan waktu belajar lebih panjang, (4) melakukan seleksi yang cukup ketat terhadap pendaftar, (5) mendapat animo yang besar dari masyarakat yang dibuktikan dengan banyaknya jumlah pendaftar dibanding kapasitas kelas, dan (6) biaya sekolah lebih tinggi dari sekolah lain di sekitarnya". ${ }^{8}$

Selain dari ciri-ciri tersebut di atas, nilai lebih dari sekolah unggul dapat dilihat dari perlakuan tambahan diluar kurikulum nasional melalui pengembangan kurikulum, program pengayaan, pengajaran remedial, pelayanan bimbingan dan konseling yang berkualitas, pembinaan kreativitas dan kedisiplinan. Atau dengan kata lain

${ }^{8}$ Ekosusilo, Madyo. 2003. Hasil Penelitian Kualitatif : Sekolah Unggul Berbasis Nilai (Studi Multi Kasus di SMA Negeri 1 Surakarta, SMA Regina Pacis, dan SMA Al-Islam 01 Surakarta). Sukoharjo : Univet Bantara Press, h.41 
Sebuah madrasah dikatakan unggul jika mampu mencetak lulusan yang memuaskan masyarakat, dan itu akan dapat terwujud jika madrasah didukung berbagai faktor yang harus ada pada madrasah.

Dari uraian diatas menunjukkan bahwa secara umum Madrasah yang dikategorikan unggul harus meliputi tiga aspek. Ketiga aspek tersebut adalah: Pertama, Input. Madrasah dapat menyeleksi siswa dengan sistem seleksi yang sangat ketat. Selain seleksi bidang akademis, juga diberikan persyaratan lain sesuai tujuan yang ingin dicapai sekolah. Kedua, Proses. Proses belajar-mengajar madrasah unggul ini setidaknya didukung oleh guru yang unggul, fasilitas belajar memadai, kurikulum berstandar internasional, metode pembelajaran yang membuat peserta didik aktif, program ekstrakurikuler yang mampu mengembangkan minat dan bakat peserta didik, dan memiliki jaringan kerjasama dengan berbagai instansi negeri maupun swasta. Ketiga, Output. Madrasah unggul harus menghasilkan lulusan yang unggul. Keunggulan lulusan tidak hanya ditentukan oleh nilai ujian yang tinggi. Indikasi lulusan yang unggul ini baru dapat diketahui setelah yang bersangkutan memasuki dunia kerja dan terlibat aktif dalam kehidupan bermasyarakat. Kemampuan lulusan yang dihasilkan dirasa unggul, bila mereka telah mampu mengembangkan potensi intelektual, potensi emosional, dan potensi spiritualnya dimana mereka berada.

\section{HASIL DAN PEMBAHASAN}

\section{Sejarah Berdiri MI Al-Istiqomah}

Madrasah Ibtidaiyah (MI) Istiqomah Sambah dibawah Yayasan Istiqomah Sambas yang berlokasi di tengah kota Purbalingga tepatnya di Jalan May. Jend. Panjaitan 61 A Purbalingga Jawa Tengah. Luas bangunan MI ini 4,500 m2 dengan luas tanah 13.253 m2. "Istiqomah Sambas" adalah nama sebuah yayasan yang didirikan pada tanggal 12 Oktober 1999 oleh Bapak H. Suchari Adi Mulyono (Alm.) besertakeluarganya.Yayasan ini berdiri karena rasa keprihatinan yang mendalam terhadap moral generasi masa depan yang semakin jauh dari nilai-nilai ajaran agama Islam. Selain itu tantangan arus globalisasi yang semakin pesat menuntut umat Islam untuk dapat menyesuaikan diri dengan menguasai ilmu pengetahuan dan teknologi. Atas dasar keprihatinan tersebut maka Bapak H. Suchari Adi Mulyono (Alm.) beserta keluarganya merasa terpanggil hati nuraninya untuk berpartisipasi dalam memajukan umat Islam dengan mendirikan sebuah Yayasan yang bergerak dalam bidang pendidikan, sosial dan keagamaan.

Sambas adalah kependekan dari nama "Suchari Adi Mulyono Banyumas Asli". Beliau adalah sosok pengusaha yang mengedepankan nilai-nilai Islam dalam menjalankan segala aktifitas kehidupannya. Karirnya yang demikian dibinanya dari bawah. Berawal dari berjualan tahu kemudian jualan rambut, sopir oplet, pedagang bulu untuk sutle cock, rice mill/penggilingan padi, kontraktor, toko mas dan beberapa usaha lain yang banyak ragamnya. Ditengah kesibukan usahanya senantiasa meluangkan waktu untuk kegiatan-kegiatan keagamaan seperti menghadiri majlis-majlis ta'lim maupun mengundang ulama atau kyai secara khusus untuk membimbing beliau dan keluarganya. Bertolak dari hikmah yang didapat dari kegiatannya tersebut beliau ingin menanamkan infestasi berdimensi 
ukhrawi yang bermanfaat bagi umat Islam dan juga mendatangkan pahala secara terus menerus hingga yaumil qiyamah.

Dalam perkembangannya MI Istiqomah Sambas mendapat sambutan positif dari masyarakat sehingga prestasi demi prestasi baik akademik maupun non akademik dapat di raih. Saat ini Peserta didik MI Istiqomah Sambas berjumlah 1.195 anak. Disamping itu lembaga pendidikan ini mengelola Pendidikan Anak Usia Dini (PAUD), SMP dan Pesantren Ma'had 'Ali Tahfidzul Quran wa Dirasah Islamiyah.

\section{Visi Dan Misi MI Istiqomah Sambas}

Visi Madrasah Ibtidaiyah Istiqomah Sambas (MIIS) adalah “ Dengan sadar mutu menjadi sekolah unggul, sekolah model dan Islami “. Sedangkan Misi MI Istiqomah Sambas Purbalingga adalah memberikan pelayanan pendidikan yang maksimal dan optimal bagi seluruh peserta didik dengan mewujudkan: Penyelenggaraan kegiatan Belajar Mengajar yang berkualitas, Penyediaan tenaga pendidik yang professional, Penyediaan sarana prasarana yang reprsentatif, Penataan lingkungan yang sehat bersih, aman, nyaman an tertib, Pembinaan rohani untuk meningkatkan kualitas iman dan taqwa bagi seluruh civitas sekolah, Mengedepankan kedisiplinan yang tinggi, Menjalin hubungan yang harmonis dengan Ikatan Orang Tua Murid (IOM), masyarakat, pemerintah maupun dunia usaha, Penerapan system managemen mutu, Pemberdaya berbagai laboratorium dan perpustakaan.

\section{Ketenagaan dan Peserta Didik}

MIIS pada tahun pelajaran 2014/2015 memiliki 66 orang guru yang terdiri dari: 19 laki-laki dan 47 perempuan dan karyawan seluruhnya 10 orang terdiri dari: orang lakilaki dan 2 perempuan. Peserta seluruhnya berjumlah 1.195 orang yang terdiri dari kelas I sebanyak 210 orang (110 laki-laki dan 100 perempuan); kelas II sebanyak 206 orang ( 97 laki-laki dan 109 perempuan); kelas III sebanyak 175 orang ( 104 laki-laki dan 71 perempuan); kelas IV sebanyak 213 orang (107 laki-laki dan 106 perempuan); kelas V sebanyak 199 orang (97 laki-laki dan 102 perempuan) dan kelas Vi sebanyak 195 orang (112 laki-laki dan 83 perempuan).

\section{Kurikulum}

Kurikulum yang diterapkan dalam Proses Belajar Mengajar adalah perpaduan antara kurikulum Kementrian Agama dan Kurikulum Kemendikbud serta kurikulum yang telah ditetapkan oleh Yayasan. MI Istiqomah Sambas juga telah melaksanakan program akselerasi (percepatan belajar) sejak tahun pelajaran 2001/2002. Bidang studi dari masing-masing kurikulum tersebut adalah:

\section{Bidang Studi Agama Islam, meliputi:}

Qur'an Hadits, Bahasa Arab, Aqidah Akhlak, Fiqih, Sejarah Kebudayaan Islam, Baca Tulis Al-Quran, Program Qiroatul Kutub (kelas IV sampai VI) dan Qiroatul Qur'an melalui metode UMMI secara intensif untuk peserta didik kelas I sampai VI, Hafalan surat-surat dalam Al-Qur'an sesuai target yang telah ditentukan dan program- 
program Pembinaan Afektif Islami sesuai dengan ketentuan madrasah.

Tabel 1. Target pembelajaran Al Qur'an metode UMMI MI Istiqomah (Tahfidz Juz 30)

\begin{tabular}{|c|c|c|c|c|c|c|c|}
\hline Kls & Smt & Target & Program & Hal/Juz & Peraga & Waktu & Materi Hafalan \\
\hline \multirow[t]{4}{*}{ I } & 1 & 1 & Jilid 1 & $1-40$ & Jilid 1 & 45 & $\begin{array}{l}\text { An Naas, } \\
\text { Al Ikhlas, } \\
\text { Al Falaq, Al } \\
\text { Lahab }\end{array}$ \\
\hline & & 2 & Jilid 2 & $1-40$ & Jilid 2 & 45 & $\begin{array}{l}\text { An Nashr, Al } \\
\text { Kafirun, Al } \\
\text { kautsar }\end{array}$ \\
\hline & 2 & 3 & Jilid 3 & $1-40$ & Jilid 3 & 45 & $\begin{array}{l}\text { Al ma'un, } \\
\text { Quraisy, Al Fii }\end{array}$ \\
\hline & & 4 & Jilid 4 & $1-40$ & Jilid 4 & 45 & $\begin{array}{l}\text { Al humazah, } \\
\text { Al Ashr, At } \\
\text { Takatsur }\end{array}$ \\
\hline \multirow[t]{3}{*}{$\|$} & 1 & 5 & Jilid 5 & $1-40$ & Jilid 5 & 45 & $\begin{array}{l}\text { Al Qoriah, Al } \\
\text { Adiyat }\end{array}$ \\
\hline & & 6 & Jilid 6 & $1-40$ & Jilid 6 & 45 & $\begin{array}{l}\text { Al Zalzalah, A } \\
\text { Bayyinah }\end{array}$ \\
\hline & 2 & 7 & $\begin{array}{l}\text { Al- } \\
\text { Qur'an }\end{array}$ & Juz1-5 & $\begin{array}{l}\text { Al- } \\
\text { Qur'an }\end{array}$ & 90 & $\begin{array}{l}\text { Al qadar, Al } \\
\text { Alaq }\end{array}$ \\
\hline \multirow[t]{2}{*}{ III } & 1 & 8 & \begin{tabular}{|l|} 
Ghorib 1 \\
(Ghorib \\
$1-14)$
\end{tabular} & Juz6-15 & $\begin{array}{l}\text { Ghorib } \\
1-11\end{array}$ & 90 & \begin{tabular}{|l} 
At Tin, Al \\
insyiriah, Ad \\
Dluha
\end{tabular} \\
\hline & 2 & 9 & \begin{tabular}{|l|} 
Ghorib 2 \\
(Ghorib \\
$15-28)$
\end{tabular} & \begin{tabular}{|l} 
Juz16- \\
30
\end{tabular} & $\begin{array}{l}\text { Ghorib } \\
12-21\end{array}$ & 90 & $\begin{array}{l}\text { Al lail, Asy } \\
\text { Syams }\end{array}$ \\
\hline \multirow[t]{2}{*}{ IV } & 1 & 10 & \begin{tabular}{|l|} 
Tajwid 1 \\
(Tajwid \\
$1-10$ )
\end{tabular} & Juz1-15 & $\begin{array}{l}\text { Tajwid } \\
1-10\end{array}$ & 90 & $\begin{array}{l}\text { Al Balad, Al } \\
\text { fajr }\end{array}$ \\
\hline & 2 & 11 & \begin{tabular}{|l|} 
Tajwid 2 \\
(Tajwid \\
11-20)
\end{tabular} & \begin{tabular}{|l} 
Juz16- \\
30
\end{tabular} & $\begin{array}{l}\text { Tajwid } \\
11-20\end{array}$ & 90 & $\begin{array}{l}\text { Al Ghosyiyah, } \\
\text { Al A'la }\end{array}$ \\
\hline V & $1-2$ & 12 & $\begin{array}{l}\text { Pengem- } \\
\text { bangan } \\
1\end{array}$ & $\begin{array}{l}\text { AQ Juz } \\
1-30\end{array}$ & $\begin{array}{l}\text { Ghorib- } \\
\text { Tajwid }\end{array}$ & 180 & $\begin{array}{l}\text { At Thoriq-37, } \\
\text { An Naba }\end{array}$ \\
\hline $\mathrm{VI}$ & $1-2$ & 13 & $\begin{array}{l}\text { Pengem- } \\
\text { bangan } \\
2\end{array}$ & $\begin{array}{l}\text { AQ Jus } \\
1-30\end{array}$ & $\begin{array}{l}\text { Ghorib- } \\
\text { Tajwid }\end{array}$ & 150 & $\begin{array}{l}\text { Pemeliharaan } \\
\text { hafalan Juz } 30 \\
\text { Penambahan } \\
\text { hafalan baru } \\
\text { Juz } 29\end{array}$ \\
\hline
\end{tabular}

Sumber: Data Primer
Tabel 2. Target pencapaian Hafalan Al Qur'an MI Istiqomah Sambas kelas I sd VI

\begin{tabular}{|l|c|l|l|l|}
\hline \multirow{2}{*}{ No } & \multirow{2}{*}{ Kelas } & \multicolumn{2}{|c|}{ Program semester } & \multirow{2}{*}{ Keterangan } \\
\cline { 2 - 4 } & & \multicolumn{1}{|c|}{ I } & \multicolumn{1}{|c|}{ II } & \\
\hline 1 & I & An Naba & An Nazi'at & Bacaan salat fardu \\
\hline 2 & II & 'Abasa & $\begin{array}{l}\text { At Talwir } \\
\text { Al Infithor }\end{array}$ & $\begin{array}{l}\text { Selalu dihafalkan } \\
\text { Setiap hari Jum'at }\end{array}$ \\
\hline 3 & III & Al Muthoffifin & $\begin{array}{l}\text { Al Insyiqoq } \\
\text { Al Buruj }\end{array}$ & Sebelum salat dhuha \\
\hline 4 & IV & $\begin{array}{l}\text { At Tariq } \\
\text { Al A'la } \\
\text { Al Ghosiyyah }\end{array}$ & $\begin{array}{l}\text { Al Fajr } \\
\text { Al Balad }\end{array}$ & $\begin{array}{l}\text { Suratan dlm juz 30 } \\
\text { Mulai dari Ad Dhuha } \\
\text { sampai An Naas }\end{array}$ \\
\hline 5 & V & $\begin{array}{l}\text { Asy Syams } \\
\text { Al lail } \\
\text { Ayat Kursi } \\
\text { Al Hasyr 21-24 }\end{array}$ & $\begin{array}{l}\text { Al baqoroh } \\
\text { Al Mu'minun } \\
\text { 1-11 }\end{array}$ & $\begin{array}{l}\text { Dihafalkan setiap hari } \\
\text { sebelum salat fardu }\end{array}$ \\
\hline 6 & VI & $\begin{array}{l}\text { Mengulang juz 30 dari An Naba' dan Juz 1 } \\
\text { Mengulang doa salat }\end{array}$ \\
\hline
\end{tabular}

Sumber: Data Primer

\section{Bidang Studi Umum, meliputi:}

Bahasa Indonesia, Matematika, Sains, Pengetahuan Sosial, Pendidikan Kewarganegaraan, Bahasa Inggris (mulai dari kls I), Olah Raga dan Kesehatan, Kesenian, Ketrampilan, Pendidikan Komputer (mulai kelas IV), Bahasa Jawa/Bahasa Daerah

\section{Manajemen Madrasah}

Secara resmi MI Istiqomah Sambas menerapkan Sistem Manajemen Mutu ISO 9001: 2008 sejak tahun 2010 dengan didapatkannya sertifikat ISO 9001 : 2008 No.D004.1.104.1.11 dari lembaga sertifikasi ISO DELTA PAS INTERNATIONAL yang berlaku selama 3 tahun dan telah diperbaharui pada tahun 2013 dengan sertifikat No.D004.1.104.02.14.

Meskipun MI Istiqomah Sambas telah menerapkan Sistem Manajemen Mutu ISO 9001 : 2008, bukan berarti terjadi dualisme sistem manajemen yang diterapkan di MI 
Istiqomah Sambas. Hal ini dikarenakan MI Istiqomah Sambas menerapkan "One System Management". Artinya, meskipun MI Istiqomah Sambas menerapkan Sistem Manajemen Mutu ISO 9001 : 2008 yang berstandar internasional tetapi referensi yang dipakai dalam penyusunan Sistem Manajemen Mutu ISO 9001 : 2008 tetap mengacu pada persyaratan perundangan yang diberlakukan oleh pemerintah, sehingga apa yang dipersyaratkan oleh pemerintah tetap terlaksana dan bahkan lebih terjamin pelaksanaannya dengan diberlakukannya Sistem Manajemen Mutu ISO $9001: 2008$. Penerapan Sistem Manajemen Mutu ISO 9001 : 2008 di MI Istiqomah Sambas dimaksudkan untuk meningkatkan mutu pelayanan pendidikan yang dilakukan MI Istiqomah Sambas sehingga mampu memberikan dan meningkatkan kepuasan pelanggan / stakeholder terkait dan kinerja madrasah.

\section{Inovasi Kurikulum}

Kurikulum yang diterapkan dalam proses belajar mengajar adalah perpaduan antara kurikulum Kementerian Agama, Kurikulum Pendidikan dan Kebudayaan, Kurikulum Propinsi dan Kurikulum yang ditetapkan yayasan. MI Istiqomah Sambas juga melaksanakan program akselerasi (percepatan belajar sejak tahun 2001/2002.

\section{Kurikulum Umum}

MI Istiqomah Sambas dalam menggunakan kurikulum umum dari Kemendikbud tidak banyak melakukan perubahan tetapi selalu adaptif terhadap perkembangan kurikulum yang berlaku. Penerapan kurikulum Umum ini untuk bidang studi umum yang meliputi: Bahasa Indonesia, Matematika, Sains, Pengetahuan Sosial, Pendidikan Kewarganegaraan, Bahasa Inggris (mulai dari kls I), Olah Raga dan Kesehatan, Kesenian, Ketrampilan, Pendidikan Komputer (mulai kelas IV) dan muatan lokal.

Dalam perkembangannya pemerintah melakukan kurikulum 2013 MI Sambas telah melakukan kerjasama dengan Universitas Negeri Semarang (UNES) dalam bentuk training tentang manajemen perangkat pembelajaran tematik terpadu dalam bentuk RPP. Dari hasil training ini dikirim ke UNES untuk dilakukan verifikasi yang untuk selanjutnya dijadikann rujukan bagi guru dalam tugas mengajar.

\section{Kurikulum Agama}

Kurikulum bidang studi agama mengacu pada Kurikulum Kementerian agama yang meliput: Qur'an Hadits, Bahasa Arab, Aqidah Akhlak, Fiqih, Sejarah Kebudayaan Islam, Baca Tulis Al-Quran, Program Qiroatul Kutub (kelas IV sampai VI) dan Qiroatul Qur'an melalui metode UMMI secara intensif untuk peserta didik kelas I sampai III, Hafalan surat-surat dalam Al-Qur'an sesuai target yang telah ditentukan dan programprogram Pembinaan Afektif Islami sesuai dengan ketentuan sekolah.

Dalam kurikulum agama, MI Istiqomah Sambas menetapkan, pertama, target pembelajaran Al Qur'an dengan metode UMMI dengan mengalokasikan 10 jam pelajaran per minggu dalam jam efektif dengan rasio peserta didik kurang lebih 12 orang dalam satu kelompok dengan menggunakan metode pembelajaran moving clas. Kedua, dikembangkan kete- 
rampilan membaca dan memahami literatur berbahasa Arab diajarkan melalui Muatan Lokal di MIIS pada kelas IV, V dan VI. Program ini merupakan quantum nahwu sharaf atau cara mudah belajar Tata Bahasa Arab. Metode ini menjawab opini yang berkembang di masyarakat bahwa belajar Bahasa Arab itu membutuhkan waktu yang cukup lama dan memiliki tingkat kesulitan yang tinggi. Pola pembelajaran Qiraatul Kutub ini diselenggarakan melalui dua strategi yaitu intensive dan inside. Pola intensive adalah pembelajaran Qiraatul kutub secara khusus selama 100 jam, sedangkan pola inside melalui pembelajaran muatan lokal dua jam pelajaran setiap minggunya. Program ini merupakan salah satu keunggulan MIIS bila dibandingkan dengan sekolah yang lain. Ketiga, penetapan target pencapaian hafalan al-Qur'an kelas 1 sd VI. Kelas I semester 1 (An Naba) dan smester 2 (An Nazi'at); Kelas II semester 1 ('Abasa) dan smester 2 (At Takwir dan Al Itfithor); Kelas III semester satu (Al Muthoffifin) dan semester dua ( Al Insyiqoq dan Al Buruj); Kelas IV semester satu ( At Tariq, Al A'la, Al Ghosiyyah) dan semester dua ( Al fajr dan Al Balad); Kelass V semester satu (Asy Syams, Al Lail, Ayat Kursi, Al Hasyr 21-24) dan semester dua ( Al Baqoroh 284-286, Al Muminun 1-11; dan Kelas VI mengulang jus 30 dari An Naba' dan Juz 1 serta mengulang Doa Salat.

\section{Muatan Lokal}

MI Isqomah Sambas juga memberlakukan kurikulum muatan lokal berupa pelajaran Bahasa Jawa, Bahasa Inggris dan Komputer. Dalam pembelajaran bahasa Jawa menggunakan kurikulum yang dikeluarkan dari provinsi Jawa Tengah yang difokuskan pada pengenalan bahasa jawa dan melestarikan tradisi jawa. Untuk bahasa Inggris lebih ditekankan pada ketrampilan berbicara. Sedang pembeljaran computer lebih ditekankan pada pengenalan perangklat keras dan pemanfaatan program seperti Microsoft office, excel, power point dan point brus.

\section{Pengembangan Diri}

Pengembangan kepribadian peserta didik ini dimaksudkan untuk membina bakat dan minat peserta didik yang dilakukan melalui berbagai kegiatan seperti: kepramukaan, dokter kecil, kader dakwah, qiroah, karate, sepak bola, badminton, tenis meja, atletik, drumband dan kegiatan kesenian berupa music dan tarian tradisional.

\section{Bimbingan Konseling}

Di MI Istiqomah Sambas tidak tersedia guru Bimbingan Konseling secara khusus tetapi diupayakan melalui kerjasama dengan RSUD Kab. Purbalingga untuk membekali pengetahuan dan ketrampilan bimbingan dan konseling guru dua kali dalam setiap minggunya setiap hari Rabu dan Sabtu jam 08.00 sd 11.00 WIB. Layanan ini diberikan untuk membantu para peserta didik yang mengalami persoalan-persoalan dalam hidupnya, baik yang berkaitan dengan pembelajaran, pengembangan karir maupun kehidupan peserta didik di rumah tangga dan lingkungannya.

Disamping itu MI ini juga menyelenggarakan konsultasi prestasi belajar peserta didik antara madrasah dengan orang tua peserta didik yang dilakukan secara periodik setiap dua bulan sekali. Acara ini 
diselenggarakan setiap Ahad pagi secara bergantian tiap kelas sesuai jadwal yang telah ditetapkan oleh Madrasah. Pada acara tersebut dibahas beberapa hal antara lain: Laporan hasil ulangan harian, laporan perkembangan kepribadian peserta didik, laporan perkembangan keterampilan peserta didik, laporan permasalahan peserta didik yang timbul di sekolah maupun di rumah, penyampaian informasi-informasi dari sekolah, pembahasan masalah yang timbul serta penyerapan aspirasi dan harapan dari orang tua atau wali murid. Kegiatan ini diawali dengan siraman rohani berupa pengajian Ahad Pagi di Aula kemudian dilanjutkan dengan konsultasi di setiap kelas yang di pandu oleh wali kelas masing-masing.

\section{Ekstrakurikuler}

Kegiatan ekstrakurikuler yang dikembangkan di MI Istiqomah Sambas terkait dengan kegiatan pengembanga diri Kegiatan ini dimaksudkan untuk membina peserta didik yang mempunyai bakat dan minat pada bidang tertentu. Kegiatan ekstra kurikuler yang diselenggarakan oleh MIIS meliputi Bahasa Inggris, Qiraatil Quran, Khithobah, Rebana, Band, Olah Vokal, Paduan Suara, Drum Band, Melukis, Jarimatika, Robotic, Karate, Sepak bola, Tenis Meja, Bulu tangkis, Atletic, Pramuka, Dokter kecil dan Komputer.Disamping itu di bulam Ramadahan diadakan kultum Da'I cilik menjelang buka puasa di Radio milik pemerintah daerah Kabupaten Purbalingga.

\section{Inovasi Pembelajaran}

Inovasi pembelajaran merupakan upaya pembaharuan terhadap berbagai komponen pembelajaran dalam penyampaian materi pelajaran untuk meningkatkan kualitas pendidikan yang berlangsung.

\section{Sistem Pembelajaran}

Sistem pembelajaran yang dikembangkan di MI Istiqomah Sambas adalah Sistem Promosi dan Degradasi merupakan program tindak lanjut dari hasil evaluasi dan analisa terhadap ketuntasan belajar peserta didik. Bagi peserta didik yang memenuhi taraf serap tuntas akan mendapat kesempatan untuk promosi atau pengayaan di kelas yang memiliki kemampuan cepat.

Sistem ini untuk menciptakan persaingan yang sehat, program layanan ini juga untuk mempermudah melakukan perbaikan bagi peserta didik yang belum tuntas dalam pencapaian hasil belajarnya. Sistim pengelompokan peserta didik sesuai dengan kemampuan taraf serapnya ini dilakukan dengan ketentuan sebagai berikut : Kelompok A apabila nilainya 8,0 ke atas; Kelompok B apabila nilainya 7,5 -7,9; Kelompok $C$ apabila nilainya 7,0 - 7,4; Kelompok D apabila nilainya 6,5 - 6,9 dan Kelompok E apabila nilainya 6,4 ke bawah. Sementara peserta didik yang belum memenuhi ketuntasan taraf serap atau mengalami degradasi makas peserta didik tersebut akan mendapatkan perlakukan khusus oleh guru pembimbing di kelas tersendiri.

Berdasar pada Undang-Undang Sisdiknas no 20 tahun 2003 pasal 12 ayat satu disebutkan bahwa setiap peserta didik pada setiap satuan pendidikan berhak menyelesaikan program pendidikan sesuai dengan kecepatan belajar masing-masing. Menyikapi amanah tersebut maka MIIS 
memiliki salah satu program unggulan yang dinamakan dengan program PATAS (cepat dan tuntas) atau yang sering disebut Program akselerasi.

Peserta didik berhak mengikuti program PATAS ini manakala memenuhi empat persyaratan yang telah ditentukan yaitu memiliki nilai akademik yang tinggi serta menduduki peringkat kelas A1, direkomendasikan oleh psycholog, lolos tes kesehatan dan mendapatkan persetujuan dari orang tua atau wali murid. Bagi peserta didik yang mampu menempuh Program Akselerasi ini dengan baik, diberikan hak untuk dapat menamatkan pembelajaran di MIIS cukup lima tahun.

\section{Tradisi PBM}

Adanya pandanagan MI Istiqomah Sambas bahwa anak mendapatkan pengalaman belajar tidak terbatas padsa waktu dan tempat. Pembelajaran dapat dilakukan di dalam dan di luar kelas bahkan di lingkungan keluarga. Pembelajaran di madrasah ini dapat dikategorikan fullday school karena melebihi dari 8 jam belajar efektif mulai waktu jam 06.15 sd 14.00. Dalam pembelajarannya juga dikembangkan pembelajaran dengan memanfaatkan alam sekitar madarasah dalam bentuk kegiatan outbound, project class atau kunjungankebeberapa objek sumber belajar seperti: ke perpustakaan daerah, Bendungan PLTA Waduk Mrican Banjar Negara, Sanggaluri Park untuk outbound maupun kegiatan ilmiah lainnya seperti bedah kodok, kadal, ular.

\section{Metode Pembelajaran}

Metode yang dikembangkan dalam pembelajaran di MI Istiqomah Sambas adalah Active Learning Starategic adalah metode pembelajaran yang lebih banyak melibatkan peran aktif peserta didik dalam proses pembelajaran. Artinya peserta didik tidak semata-mata menjadi objek tetapi menjadi subjek pembelajaran. Disamping itu diterapkan azas didaktik metodik secara kretaif dalam pembelajaran. Namun dalam pembentukan sikap (afeksi) dalam penanaman karakter dapat dilakukan melalaui tahapan peserta didik tahu, bisa, terbiasa dan berani mengingatkan kepada teman sejawatnyabila kedapatan melakukan perilaku yang tidak sesuai dengan aturannya, seperti bila ada temannya yang makan berdiri maka peserta didik ybs mencoba mengingatkan untuk tidak makan berdiri atau diminta untuk duduk. Penanaman ini menjadi tanggung jawab seluruh guru MI Istiqomah tidak terbatas pada guru pendidikan agama saja.

\section{Kreativitas PenggunaanTeknologi Informasi (TI)}

MI Istiqomah Sambas memiliki jaringan intranet dan internet. Intranet merupakan server yang dimiliki madrasah yang berisi bahan seluruh sumber belajar berupa buku atau referensi. Untuk intranet sudah ada petugas khusus yang menanganinya dan dapat dimanfaatkan para guru dalam pembelajaran di kelas karena di setiap ruang kelas tersedia LCD. Dengan kata lain peserta didik sudah diperkenalkan pembelajaran dengan menggunakan TI baik untuk materi pembelajaran maupun dalam bentuk audio visual lainnya. Sedangkan jaringan internet 
juga sudah dapat diakses di setiap kelas melalui jaringan hotspot area yang mampu diakses oleh seluruh warga madrasah.

\section{Inovasi Manajemen}

Inovasi manajemen pendidikan merupakan upaya pembaharuan dari berbagai komponen pendidikan yang saling membantu demi tercapainya tujuan pendidikan yang telah ditetapkan.

\section{Kepemimpinan}

Ada prinsip yang harus dilakukan oleh Kepala Madrasah bahwa terhadap aturan yang sudah ditetapkan baik oleh madrasah maupun pemerintah harus dilaksanakan secara tegas. Namun terkait dengan inovasi-inovasi dapat dibicarakan dan dimusyawarahkan dengan seluruh stakeholders (kepala sekolah, TU, guru, pengawas dan komite, yayasan maupun pengguna jasa pendidikan).

Managemen MI Istiqomah Sambas telah menerapkan ISO-2001:2008 dan telah dilakukan akreditasi dua kali pada tahun 2010 dan 2013 dengan predikat "A". Budaya yang ditanamkan adalah budaya kerja, budaya mutu dan budaya malu. Budaya kerja, setiap guru dan karyawan harus betul-betul memiliki kinerja sebagaimana yang telah dipersyaratkan oleh madrasah. Budaya mutu, setiap aktivitas individu dalam layanan pendidikan di MI Istiqomah Sambas harus berpedoman mutu yang telah ditetapkan. Madrasah ini telah memiliki prinsip output adalah akumulasi dari setiap tahapan proses yang bermutu. Artinya bahwa setiap guru maupun karyawan dalam setiap saat harus mengeluarkan produk yang bermutu. Sedangkan budaya malu, suluruh guru dan karyawan merasa malu bilamana yang dilakukan tidak sesuai dengan harapan yang ditentukan oleh madrasah atau belum mencapai target yang ditetapkan.

\section{Tata Kelola}

Azas yang dikembangkan dalam tata kelola di MI Istiqomah Sambas adalah Total Product Concept melalui tahapan Generic, Ekspective, Aughmented dan Potencial. Tahap generic, melakukan kegiatan sebagaimana yang dilakukan madrasah atau sekolah lain yang sifatnya sangat mendasar. Ekspective, layanan sesuai dengan harapan para pengguna layanan pendidikan di MI Istiqomah Sambas. Aughmented, menyuguhkan sesuatu yang tidak mereka minta oleh pengguna jasa pendidikan tetapi MI Istiqomah dapat memberikannya dan umumnya mereka atau jasa pendidikan mngucapkan terima kasih. Sedangkan Potencial, sesuatu yang akan muncul di kemudian hari akan diberikan layanan seperti system pembelajaran promosi dan degradasi bagi peserta didik.

\section{Budaya Madrasah}

Bahwa yang dilakukan oleh MI Istiqomah dalam mengembangkan budaya madrasah dengan cara mengambil jalan tengah tidak condong pada organisasi keagamaan tertentu mengingat latar belakang peserta didik berasal dari berbagai kalangan. Dasar penanaman nilai nilai agama melalui 1) penanaman kecintaan terhadap Al Qur'an, diwujudkan dengan kemampuan baca tulis Al Qur'an dengan baik 2) Kemampuan mengetahui terjemahan, 3) kemampuan untuk mengetahui struktur kalimat yang ada dalam al Qur'an kemudian 4) semangat 
yang dikembangkan dalam nilai-nilai yang ditanamkan dalam Al Quran.

Layanan bimbingan baca al-Quran dimaksudkan untuk menjadikan peserta didik cinta terhadap Kitab Suci al-Quran. Programinidiberikan semenjak peserta didik berada di kelas satu pada awal masuk MIIS dengan target empat bulan harus mampu membaca al-Quran. Untuk memperlancar bacaan al-quran setiap hari seluruh peserta didik kelas I s.d. kelas III MIIS sebelum pembelajaran dimulai senantiasa dilakukan tadarus al-Quran dengan program tahsin dan tahfidzil Quran. Sedangkan peserta didik kelas IV s.d. kelas VI selain tahsin dan tahfidzil Quran juga menterjemah dan meng-i'rab al-Quran.

Adapun layanan ibadah dilakukan guna menumbuhkan kesadaran dan pembiasaan peserta didik untuk melakukan berbagai amaliah ibadah yaumiah atau ibadah harian seperti shalat dhuhur berjamaah, dzikir, berderma, afsussalaam (menebarkan salam), shalat dhuha, dll.

\section{Jaringan Kerjasama}

MI Istiqomah Sambas telah menjalin hubungan kerjasama secara nasinal dengan 1) Bayt Tamzis Indramayu, untuk mengembangkan program qiraatul Kutub, 2) UMMI FondationBandung, untuk mengembangkan program Qiraatul Qur'an, 3) RSDD Kab. Purbalingga, untuk kerjasama dibidang bimbingan konseling, 4) Media Konsultas Bogor, untuk pengembangan system manajemn mutu, 5) Delta Pas Internasional Bogor, untuk pelaksanaan sertifikasi ISO 2001:2008, 6) UNES, untuk pengembangan kurikulum dengan focus pengembangan kegiatan PBM dan 7) Dewan
Dakwah Islamiyah, untuk pembinaan Kader Dakwah. Dakwah adalah kewajiban bagi setiap individu untuk melakukan perbaikan dan pencerahan kepada diri maupun masyarakat di sekitarnya. Dalam upaya mencetak kader-kader dakwah masa depan, MIIS menyelenggarakan pelatihan dai kecil yang ditampilkan diberbagai acara pengajian di masyarakat maupun disiarkan melalui radio yang ada di Purbalingga setiap bulan Ramadhan menjelang buka puasa

Juara I Lomba Mata Pelajaran madrasah Tingkat Kabupaten, Juara I Lomba Drum Band SD se Eks Karisidenan Banyumas, Lomba FASI I Tingkat Propinsi dan salah satu pemenang Lomba Sekolah Sehat SD / MI Tingkat Nasional Tahun 2004.

\section{Daya Serap}

Animo masyarakat untuk menyekolahkan putra putrinya di MI Istiqomah Sambas cukup tinggi terbukti tahun 2014 jumlah pendaftar 317 orang dan hanya diterima sebanyak 210 orang jadi sekitar 102 orang (48\%) yang tidak diterima. Sedangkan tahun ini 2015 yang telah menitipkan akte ke madrasah berjumlah 290 orang padahal pendaftaran belum dibuka secara umum masih 1 bulan lagi. Artinya Mi Istiqomah Sambas belum dapat menerima seluruh pendaftar yang diakibatkan oleh terbatsanya jumlah ruang kelas dan lahan.

\section{Diskusi}

Madrasah sebagaimana lembaga pendidikan umum lainnya dituntut untuk dapat memenuhi harapan masyarakat sesuai dengan tujuan pendidikan nasional yaitu menjadikan peserta didik menjadi anak yang bertaqwa kepada Tuhan yang 
Mahaesa, cerdas, berkepribadian, memiliki ketrampilan dan memiliki kemandirian. Untuk itu madrasah harus memiliki kekhasan atau keunggulan serta kualitas dalam berbagai hal, seperti ketersediaan sarana dan prasarana, pendidik dan tenaga kependidikan, sarana dan prasarana, anggaran, kegiatan belajar mengajar, prestasi peserta didik dan dan keterlibatan masyarakat terhadap penyelenggaraan pendidikan di madarasah.

\section{Analisis Kekhasan dan Keunggulan}

Bahwa MI Istiqomah Sambas Purbalingga Jawa Tengah berdasarkan data dan informasi sebagaimana uraian di atas maka dapat dikategorikan sebagai MI Unggulan dalam mengemban amanah di bidang pendidikan dasar. Indikasinya bahwa banyak layanan pendidikan yang ditawarkan oleh MI Istiqomah Sambas sesuai dengan harapan orang tua dan masyarakat dalam mengembangkan bakat dan minat peserta didik.

Berbagai layanan pendidikan yang ditawarkan oleh MI Isqtiqomah Sambas antara lain pengelolaan madrasah berbasis Sistem Manajemen Mutu (ISO 9001:2008), program akselerasi (percepatan waktu belajar), bimbingan baca Qur'an dan ibadah, Qiraatul Kutub, promosi dan degradasi, dan pembelajaran berbasis IT.

Penerapan Sistem Manajemen Mutu ISO 9001 : 2008 di MI Istiqomah Sambas dimaksudkan untuk meningkatkan mutu pelayanan pendidikan yang dilakukan MI Istiqomah Sambas sehingga mampu memberikan dan meningkatkan kepuasan pelanggan / stakeholder terkait dan kinerja madrasah. Penerapan system manajemen mutu dalam rangka memberikan pelayanan pendidikan untuk membentuk Peserta Didik Unggul, Mandiri, Kreatif dan Islami adalah prinsip dasar penyelenggaraan pendidikan MI Istiqomah Sambas yang terus dikembangkan sesuai tuntutan jaman. Untuk menjaga konsistensi dalam penerapan prinsip tersebut diatas MI Istiqomah Sambas menerapkan suatu sistem manajemen mutu yang difokuskan pada perbaikan berkesinambungan setiap aspek khususnya sumber daya dan peningkatan profesionalisme guru. Direktur dan seluruh staf memiliki komitmen kuat dalam penerapan dan pencapaian setiap tujuan dan sasaran yang terkait dengan kebijakan mutu ini.

Program akselerasi atau percepatan waktu belajar dilaksanakan berdasarkan Undang-Undang Sisdiknas no 20 tahun 2003 pasal 12 ayat satu disebutkan bahwa setiap peserta didik pada setiap satuan pendidikan berhak menyelesaikan program pendidikan sesuai dengan kecepatan belajar masingmasing. Program ini diperuntukan bagi Peserta didik yang memiliki nilai akademik yang tinggi serta menduduki peringkat kelas A1, direkomendasikan oleh psycholog, lolos tes kesehatan dan mendapatkan persetujuan dari orang tua atau wali murid. Bagi peserta didik yang mampu menempuh Program Akselerasi ini dengan baik, diberikan hak untuk dapat menamatkan pembelajaran di MIIS cukup lima tahun.

Bimbingan baca Qur'an dan ibadah merupakan bentuk layanan pendidikan yang dimaksudkan untukuntuk menjadikan peserta didik cinta terhadap Kitab Suci alQuran. Program ini diberikan semenjak peserta didik berada di kelas satu pada awal masuk MI Istiqomah Sambas dengan target 
empat bulan harus mampu membaca alQuran. Adapun layanan ibadah dilakukan guna menumbuhkan kesadaran dan pembiasaan peserta didik untuk melakukan berbagai amaliah ibadahyaumiah atau ibadah harian seperti shalat dhuhur berjamaah, dzikir, berderma, afsussalaam (menebarkan salam), shalat dhuha, dll.

Dalam rangka memberikan ketrampilan peserta didik dalam membaca dan memahami literatur berbahasa Arab MI Istiqomah memberikan program qiraatul Kutub dengan metode UMMI yang diajarkan melalui Muatan Lokal di MIIS pada kelas IV, V dan VI. Program ini merupakan quantum nahwu sharaf atau cara mudah belajar Tata Bahasa Arab. Metode ini menjawab opini yang berkembang di masyarakat bahwa belajar Bahasa Arab itu membutuhkan waktu yang cukup lama dan memiliki tingkat kesulitan yang tinggi. Pola pembelajaran Qiraatul Kutub ini diselenggarakan melalui dua strategi yaitu intensive dan inside. Pola intensive adalah pembelajaran Qiraatul kutub secara khusus selama 100 jam, sedangkan pola inside melalui pembelajaran muatan lokal dua jam pelajaran setiap minggunya.

Untuk menciptakan persaingan yang sehat, maka MI Istiqomah menyelenggarakan program promosi dan degradasi untuk mempermudah melakukan perbaikan bagi peserta didik yang belum tuntas dalam pencapaian hasil belajarnya. Program ini merupakan tindak lanjut dari hasil evaluasi dan analisa terhadap ketuntasan belajar peserta didik. Bagi peserta didik yang memiliki taraf serap tuntas mendapat kesempatan untuk promosi atau pengayaan di kelas yang peserta didiknya memiliki kemampuan cepat, sedangkan peserta didik yang belum tuntas atau menurun prestasinya (degradasi) mendapatkan perlakuan khusus di kelas tersendiri untuk diberikan perbaikan secara intensive. Metode pembelajaran yang dikembangkan di MI ini mengedepankan active learning strategic, dengan menitikberatkan pada keaktifan peserta didik. Untuk mata pelajaran agama, metode pembelajarannya menggunakan scientitik dengan 5 tahapan utama yaitu aktivitas untuk mengamati, menanya, mengeksplorasi, mengasosiasi/ menalar dan mengkomunikasikan kepada peserta didik.

Sedangkan untuk kegiatan PBM di MI Istiqomah Sambas telah dilengkapi sarana intranet dan internet. Ketersediaan sarana ini mendorong guru untuk menciptakan metode pembelajaran yang menarik dan sekaligus memperkenalkan TI kepada peserta didik. Seluruh bahan pembelajaran sudah dimasukan dalam program intranet yang sewaktu-waktu dapat dilihat guru dalam proses pembelajaran di kelas. Untuk memperkaya materi pembelajaran tersebut dapat juga diambil dari internet karena MI ini sudah dilengkapi hotspot area yang sewaktu-waktu dapat mendukung kegiatan pembelajran di kelas. TI sudah dimanfaatkan dengan baik dalam kegiatan PBM. Dalam rangka menunjang $\mathrm{PBM}$ di masingmasing kelas sudah terpasang LCD berta kelengkapannya termasuk sounsystem. Guru sudah terbiasa menggunakan model presentasi dalam pemaparan materi pembelajarannya, juga menayangkan gambar/data/video serta penayangan $C D$ pembelajaran. 


\section{Faktor Pendukung Dan Kendala}

\section{Sarana dan Prasarana}

MI Istiqomah Sambas telah dilengkapi sarana dan prasarana penyelenggaraan pendidikan yang cukup memadai tidak hanya disediakan ruang kelas tetapi juga tersedia ruang lain seperti ruang kepala madrasah, Ruang Guru, Perpustakaan, Ruang UKS, Ruang Ibadah/Musholla, Kamar Mandi/ WC, Kantin Sekolah, Ruang Komputer, Ruang Tata Usaha/Administrasi, Aula, Lapangan Olah Raga, dll. Disamping itu tersedia prasarana seperti: Intranet dan internet, Komputer, LCD, CCTV, Televisi 24 inchi, Alat Musik Band, Alat Musik Rebana. Adapun titik lemah dari sarana prasarana yang tersedia adalah terbatasnya lahan untuk membangun ruang kelas baru dan asrama peserta didik menjadikan MI boarding school.

\section{Pendidikan dan Tenaga Kependidikan}

Kompetensi dan kualifikasi guru MI Istiqomah Sambas saat ini telah memenuhi persyaratan sebagaimana diatur dalam sistem manajemen mutu ISO 9001:2008. Bahwa setiap guru dan karyawan harus betulbetul memiliki kinerja sebagaimana yang telah dipersyaratkan oleh madrasah. Untuk memenuhi standar kompetesi dan kualifikasi tersebut dilakukan berbagai pemberdayaan tenaga pendidik dan kependidikan melalui kegiatan pendidika dan pelatihan, seminar, workshop, simposium atau kegiatan sejenisnya baik yang diselenggarakan oleh Dinas dikbud maupun Kemenag kabupaten. Pengembangan tenaga pendidik dan kependidikan dilaksanakan melalui peningkatan kualifikasi kepala madrasah dan guru. Paling tidak kepala madrasah dan guru berkualifikasi jenjang pendidikan S1 atau setara, memiliki kemampuan teknik pembelajaran, kemampuan manajerial, berkepribadian baik dan menarik. Pemenuhan kualifikasi ini dilaksanakan secara bertahap di madrasah. Sedangkan tenaga TU perlu memiliki kemampuan dan keterampilan sesuai bidangnya yaitu melayani kebutuhan adminstrasi kepegawaian maupun akademik. Disamping itu dikembangkan budaya mutu dan budaya malu. Budaya mutu, setiap guru maupun karyawan MI Istiqomah Sambas harus mengeluarkan produk yang bermutu. Sedangkan budaya malu, suluruh guru dan karyawan merasa malu bilamana yang dilakukan tidak sesuai dengan harapan yang ditentukan oleh madrasah atau belum mencapai target yang ditetapkan. Jumlah pendidik di MI ini seluruhnya 66 orang ( 6 PNS dan 60 Swasta) tingkat keterpenuhannya baru mencapai 96\% dilihat dari jumlah seluruh siswa (1195 orang). Sedangkan jumlah tenaga kependidikan seluruhnya 25 orang (5 tenaga administrasi, 2 tenaga perpustakaan, 2 tenaga laboratorium IPA, 3 Satpam dan 8 orang tenaga kebersihan), tingkat keterpenuhannya baru $80 \%$. Dilihat dari tingkat keterpenuhan tenaga pendidikan dan kependidikan maka kedepannya perlu diangkat kembali dalam rangka memenuhi kekurangannya.

\section{Ketersediaan Anggaran}

Sumber pembiayaan di MI Istiqomah Sambas dalam mendukung kegiatan pembelajaran berasal dari: 1) orang tua dan wali siswa (Per bulan Rp. 105,000, @ siswa), 2) Dana BOS (Per bulan Rp.66.66,- @ siawa), 3) Donatur Yayasan, 4) Hasil usaha (layanan antar jemput siswa, layanan fotocopi, kantin, 
jasa konpeksi, kantin sekolah dan koperasi). Ke depan, dari jumlah sumber pembiayaan ini dirasa masih perlu ditingkatkan seiiring dengan meningkatnya operasional kegiatan ekstrakurikuler dalam mewujudkan minat dan bakat peserta didik.

\section{Kegiatan Belajar Mengajar}

Struktur kurikulum yang dijadikan dasar guru menyusun kurikulum, mengacu kepada struktur kurikulum yang diterbitkan Pendidikan dan Kebudayaan \& struktur kurikulum yang diterbitkan Kementerian Agama dan ditambah dengan kurikulum muatan lokal (sekolah/lokal) dari provinsi seperti: Bahasa Jawa dan Inggris. Sistem pembelajaran yang dikembangkan di MI Istiqomah Sambas adalah Sistem Promosi dan Degradasi merupakan program tindak lanjut dari hasil evaluasi dan analisa terhadap ketuntasan belajar peserta didik. Bagi peserta didik yang memenuhi taraf serap tuntas akan mendapat kesempatan untuk promosi atau pengayaan di kelas yang memiliki kemampuan cepat. Sistem ini untuk menciptakan persaingan yang sehat, program layanan ini juga untuk mempermudah melakukan perbaikan bagi peserta didik yang belum tuntas dalam pencapaian hasil belajarnya. Sistem ini dapat mendorong peserta didik untuk giat belajar baik yang memiliki kemampuan tinggi maupun rendah. Peserta didik yang memiliki kemampuan tinggi maka peserta didik yang bersangkutan akan mendapat promosi untuk materi yang lebih tinggi bahkan akan mendapat percepatan studi 6 tahun menjadi 5 tahun. Sementara peserta didik yang memiliki kemampuan rendah akan tetap memacu untuk dapat menyelesaikan ketuntasannya. Untuk meningkatkan kualitas PBM di MI Istiqomah sambas juga dilakukan upaya peningkatan kualitas dan kelengkapan perangkat pembelajaran (Silabus, RPP dan bahan Ajar); optimalisasi sarana prasarana dan lingkungan yang tersedia baik di dalam maupun di luar madrasah dalam mendukung pelaksanaan pembelajaran; optimalisasi pengawasan proses pembelajaran; dan tindak lanjut perbaikan pelaksanaan pembelajaran secara periodik. Guru harus memiliki kemampuan materi ajar dan dapat memilih metode pembelajaran yang tepat dan sekaligus mampu mengevaluasi hasil belajar.

\section{Prestasi Peserta Didik}

MI Istiqomah Sambas selalu meningkatkan prestasi akademik maupun non akademik melalui program bina prestasi atau penyaringan bakat-minat dalam proses pembelajaran di kelas maupun dalam kegiatan ekstrakurikuler. MI ini senantiasa mengirimkan perwakilannya dalam kegiatan perlombaan/kompetisi yang diselenggarakan baik pada tingkat kabupaten, provinsi maupun nasional.

Prestasi yang telah diraih MI Istiqomah Sambas pada tingkat nasional dalam bentuk juara kompetisi Saint Madrasah tahun 2014, Madrasah Berprestasi, Sekolah Sehat SD/MI, dan Finalis Olimpiade Online Nasional yang diselenggarakan oleh Habibie Centre. Pada tingkat provinsi menjadi juara II Adzan \& Iqomah, Juara I Guru Teladan, Juara I Lomba Sekolah Sehat SD/MI, Juara I Lomba Sekolah Sehat MI, Juara Harapan III Olimpiade IPA. Sedangkan pada tingkat kabupaten pernah menjadi juaraJuara I Drum Band SD/MI,Juara Umum Apresiasi MI, Juara I Lomba Sekolah Sehat SD/MI, Juara I Lomba Sekolah Sehat Madrasah, Juara I Puitisasi Al Qur'an Putra, 
dll. Sedangkan pada tingkat kecamatan pernah menjadi juara Juara I MTQ pelajar, Juara I Seni Islami, Juara I Bidang Study IPA, Juara I Bidang Study Matematika, Juara I Bidang Study Bhs. Indonesia, Juara I Bidang Study Bhs. Arab, Juara I Lomba Pidato Bahasa Arab Putri, Juara I Lomba Pidato Bahasa Arab Putra, Juara I Lomba Pidato Bahasa Jawa Putra dll.

\section{Keterlibatan Masyarakat}

Dukungan masyarakat terhadap MI Istiqomah Sambas sangat tinggi terlihat dari animo masyarakat untuk menyekolahkan putra putrinya dalam setiap tahunnya melebihi dari daya tampung yang dimiliki oleh madrasah ini. Sebagai gambaran pada tahun ini meskipun pendaftaran secara resmi dari pemerintah belum dimulai namun masyarakat yang menitipkan akte kelahiran calon siswa sudah mencapai 296 orang sementara daya tampung yang dimiliki madrasah sebanyak 250 orang. Disamping itu tingginya partisipasi orang tua/wali murid dan tokoh masyarakat dalam setiap kegiatan Madrasah "mereka selalu datang dan mendukung", apalagi kalau ada undangan silaturrahmi dengan para orang tua murid, mereka selalu datang," papar Arifin, kepada madrasah dan diaminkan oleh beberapa guru setempat.

\section{Peran Pemerintah}

\section{Peranan Kemenag Tingkat Kabupaten}

Kemenag memberikan pembinaan secara periodik dalam bentuk pemikiran strategis untuk membangun dan mewujudkan madrasah yaang berkualitas baik secara akademik maupun non-akademik dalam mewujudkan peserta didik yang beriman, bertaqwa, berakhlaqulkariimah, berpengetahuan luas, terampil yang ditandai dengan kemampuan hidup mandiri, bertanggung jawab serta mampu mengabdikan dirinya untuk agama, bangsa dannegaranya.Kemenagjugamemanfaatkan peluang atas dukungan masyarakat terhadap keberadaan madrasah untuk lebih solid dan mampu bersaing dengan sekolah umum dengan cara mengembangkan kreativitas sumber daya madrasah berdasarkan aspirasi masyarakat setempat seperti: dukungan Kemenag terhadap berbagai perlombaan baik pada tingkat kabupaten, provinsi maupun nasional.

\section{Keberpihakan Pemerintah Daerah}

Terkait dengan pengembangan pendidikan madrasah, pemerintah Kabupaten Purbalingga tidak memiliki kebijakan khusus. Hal ini didasarkan pada anggapan bahwa pendidikan madrasah tidak berbeda dengan pendidikan umum atau pendidikan lainnya, baik menyangkut kebijakan dalam pengembangan kurikulum, kebijakan pembinaan tenaga pendidik, maupun kebijakan dalam pengadaan sarana dan prasarana pendidikan.

\section{PENUTUP}

\section{Kesimpulan}

MI Istiqomah Sambas (MIIS) Purbalingga Jawa Tengah merupakan sekolah unggul, model dan Islami. Unggul, sebagai sekolah yang menerima peserta didik dengan kemampuan biasa menjadi unggul yang berakal budi dan berakhlak mulia, berwawasan luas terbuka terampil dan kreatif. Model, sebagai sekolah rujukan 
bagi lembaga lain karena ide-ide inovasi dibidang pendidikan dan Islami, sekolah dapat menciptakan nuasa keislaman bagi guru, peserta didik dan lingkungan sekitar.

MIIS dalam proses pendidikannya mengacu pada kurikulum umum Kemendikbud untuk bidang umum, kurikulum agama dari Kemenag untuk bidang studi agama dan kurikulum muatan lokal dari pemerintah provinsi untuk bidang studi bahasa Jawa.

Program unggulan MIIS yang menjadi ciri khas adalah program akselerasi (percepatan waktu belajar), bimbingan baca Al-Qur'an (Metode UMMI) dan ibadah, Qiraatul Kutub, sistem pembelajaran Promosi dan Degradasi, pembelajaran berbasis IT dan berprestasi dalam berbagai perlombaan baik pada tingkat kabupaten, provinsi maupun nasional.

MIIS mengembangkan azas tata kelola dalam bentuk Total Product Concept melalui tahapan Generic, Ekspective, Aughmented dan Potencial. Tahap generic, melakukan kegiatan sebagaimana yang dilakukan madrasah/ sekolah lain yang sifatnya sangat mendasar. Ekspective, layanan sesuai dengan harapan stakeholders. Aughmented, menyuguhkan sesuatu yang tidak diminta stakeholder. Sedangkan Potencial, sesuatu yang akan muncul di kemudian hari akan diberikan layanan seperti system pembelajaran promosi dan degradasi bagi peserta didik.

MIIS masih menghadapi kendala: 1) perluasan lahan untuk membangun asrama peserta didik menjadikan madrasah sebagai boarding school; 2) pemenuhan tenaga pendidik dan kependidikan dan 3) terbatasnya daya tampung calon peserta didik.

\section{Rekomendasi}

MIIS perlu meningkatkan kerjasama dengan Kepala Daerah, Kemenag dan tokoh masyarakat kabupaten Purbalingga dalam perluasan lahan di sekitar madrasah, pemenuhan pendidik dan tenaga kependidikan, daya tampung calon peserta didik.

Sementara itu pada aspek pelayanan MIIS perlu meningkatkan mutu pelayanan pendidikan untuk membentuk peserta didik yang unggul, mandiri, kreatif dan Islami dengan melibatkan seluruh stakeholders (Kepala madrasah, guru, pengawas dan seluruh staf MIIS). 


\section{SUMBER BACAAN}

Abudinata (2011): Reposisi Madarsah dalam Memasuki Indonesia Baru, makalah disampaikan pada seminar Evaluasi Kurikulum Madarsah Tahun 1994 Jakarta, Litbang Depag RI, 6-7 Desember 1999.

Azizah, Nur (2012): Madrasah Unggulan dan Madrasah Model, Makalah disajikan pada Seminar teknologi Pendidikan di Institut Islam Negeri Sunan Ampel Surabaya.

Depdikbud (1994): Pengembangan Sekolah Unggul. Jakarta, Dirjen Dikdasmen

Djohar (2002):Pendidikan:AlternatifPendidikan Masa Depan. Yogyakarta, LESFI.

Ekosusilo, Madyo (2003): Hasil Penelitian Kualitatif: Sekolah Unggul Berbasis Nilai (Studi Multi Kasus di SMA Negeri 1 Surakarta, SMA Regina Pacis, dan SMA AlIslam 01 Surakarta). Sukoharjo, Univet Bantara Press.
Jalal, Fasli (2012): Slide presentasi Strategi dan Arah Pengembangan Sekolah Unggul, diunduh tangal 12 Juni 2012

Maimun, Agus dan Fitri, Agus Zaenul (2010): Sekolah Unggulan Lembaga Pendidikan Alternatif di Era Kompetitif. Malang, UIN Maliki Press.

Muhammad (Januari 2009): Konsep Pengembangan Madrasah Unggul. Kreatif, Vol. 4, No. 1.

Mastuhu (2002): Menata Ulang Pendidikan Nasional Abad 21. Jakarta, INIS

Makalah Direktur Madrasah, Dedi Zubaidi yang diprentasikan pada acara Workshop Perencanaan Puslitbang Penda dan Keagamaan, tanggal 25 Pebruari 2015 di Gedung Pusdiklat Kementerian Agama Ciputat, Banten.

Salim, Peter dan Yenny Salim (1991): Kamus Bahasa Indonesia Kontemporer. Jakarta, Modern English Press. 